\title{
INTERNAL CONTROL MECHANISMS DURING THE STATE OF EMERGENCY - CHALLENGES IN EFFICIENT USE OF PUBLIC FUNDS
}

\author{
Daniel CONSTANTIN ${ }^{a *}$, Marius Silviu CULEA ${ }^{b}$ \\ ${ }^{a, b}$ Dunărea de Jos" University of Galati, Romania
}

DOI: $10.24818 / \mathrm{IMC} / 2020 / 05.12$

\begin{abstract}
The emergence and rapid worldwide spread of the new virus has put the entire society in a state of uncertainty as to the nature and intensity of responses to it. Given the exceptional and novel nature of this situation, in the period immediately following the emergence of this threat, the states of the world have sought and adopted various response mechanisms. Romania was not bypassed by this new situation, the local responses being dependent on domestic resources. This approach aims to examine the extent to which internal control mechanisms have contributed or could have contributed to the efficient use of public funds during the state of emergency.
\end{abstract}

KEYWORDS:, control, efficient, funds, management, public.

\section{INTRODUCTION}

"We were prepared, things were under control!" - a statement that all of us would have wanted to be true. In fact, this was not nearly like that during the global crisis caused by the new Coronavirus. The states of the world and implicitly all organizations, regardless of their size, public or private, have encountered serious problems caused by this pandemic, requiring consistent efforts and a fundamental rethinking of the defense and protection tools against economic and social consequences. As part of these efforts, managers were forced to adapt the mechanisms of the internal control system in order to reduce or limit the negative effects, such as, on the one hand, protecting the health of employees, maintaining the competitiveness of the organization, relations with business partners and, on the other hand, waste of resources or fraud.

\section{MANUSCRIPT}

\subsection{The main threats - general considerations}

After the beginning of the global Coronavirus pandemic, a number of new circumstances have emerged and led to a fundamental rethinking of the activities carried out within the organizations.

The main threat was the preventing of the transmission of the virus and the infection of their own employees or customers, in this sense being imperatively necessary to identify several areas of action (PricewaterhouseCoopers, 2020).

The first area that required action was physical access within the organization, which is essential to prevent an infected person from entering and spreading the virus. Further actions were needed to ensure health and safety at work, measures that provided additional guarantees and increased the confidence of their own employees, while identifying people who had direct contact or were suspected of COVID-19. Employee comfort and well-being was another area of action for which managers had to take action, with the risk that they would feel isolated and anxious due to the fact

\footnotetext{
${ }^{*}$ Corresponding author. E-mail address: dan.constantin@ugal.ro
} 
that they are separated from their social relationships and interactions, on the one hand, and on the other hand, absences due to illness or the care of relatives may increase.

Another action area was improving communication with third parties, in order to avoid uncertainty from relations with business partners or even public opinion, in the case of government organizations.

Remote work has also generated significant challenges due to lack of IT infrastructure capabilities, threats of cyber-attacks or lack of productivity from home. Employee mobility had to be taken into account due to travel restrictions imposed by the governments of pandemic affected countries.

\subsection{The internal managerial control system during the pandemic}

In order to provide an adequate response, the internal management control system must focus on the sensitive areas affected by the Covid-19 crisis, in order to prevent the transmission of the virus and the infection of its own employees or customers.

To secure physical access within the organization, measures are needed to redesign access policies and procedures, to ensure the safe entry and exit of employees and visitors, including ensuring physical distance and hygiene, and to assess risks in order to identify and control security risks (The Risk Coalition, 2020).

Ensuring health and safety at the workplace also requires a risk assessment of installations and workstations, to identify health status, safety risks and gaps controls related to COVID-19 pandemic, while developing a policy that contains COVID-19 guidelines, such as physical distance and hygiene that can be applied in all areas of the organization.

Employee comfort and well-being is another area of action that encourages managers to take steps to obtain bottom-up feedback, to monitor employee well-being, or to regularly check in with their teams while implementing new digital tools to support interactions with employees.

Measures are needed to improve communication with external parties to ensure that external communications policies are reviewed in order to obtain assurance that all external partners have received accurate and timely information on the operational reliability of the organization, as well as measures to monitor and evaluate responses from customers and suppliers in connection with the impact of Covid-19 on their own business operations.

Remote work also requires efforts for the internal control system, which must assess its impact on the continuity of critical security functions as well as for assessing connectivity and identifying gaps in process automation. Measures are also needed to raise awareness of cyber threats and to create remote security policies.

It is necessary to assume that increased use of teleworking will bring major changes in processes and interfaces. This has repercussions on the risk process, the adequacy of the controls in place and, ultimately, on the overall effectiveness of the internal control system.

The degree to which a company is affected by changes in the internal control system depends on the degree of automation of the processes in question. Companies with well-developed automated controls will have to face different challenges than organizations that have manual controls.

\subsection{Risk management in times of crisis}

Although there are different risk management frameworks, the fundamental elements of risk management can be considered as follows: risk identification, risk assessment, risk reduction, risk monitoring and reporting. However, what is usually missing from these models is a clear relationship with the organization's decision-making process. Indeed, if more and more money is spent on a risk-taking environment that employs more and more people, the result should be associated with better decision-making, due to greater awareness and understandings of risk events (The Risk Coalition, 2020).

Otherwise, it can simply create another problem on the business. Unfortunately, although a lot of energy has been spent on implementing the above standard process, there is still a large gap in 
trying to link the risk management function with the strategic direction of the organization in a dynamic way.

Given the economic effects of the COVID-19 crisis, new risks may arise or previously identified risk assessments should be reviewed as the magnitude and likelihood of distortion have changed. Risk methodologies need to evolve towards better quantitative standards if they are to influence executive decision-making.

It is very likely that most organizations have had such a pandemic crisis event on the risk register. Such events are usually assessed as having a low probability but a severe or major impact on the continuity of the organization's activity. It is interesting to know how such an assessment relates to risk appetite which could say: "in case of a pandemic, we should be able to continue to operate $\mathrm{x} \%$ of our business and not lose more than y monetary units, ensuring at the same time the maximum safety of our staff ”.

How can investment in digitization and communication technologies be further justified to ensure resilience if measuring the organization's risk for such an event is "low probability / severe impact"? How is this investment prioritized over the mitigation of other competing risk events with the same probability / impact categorization?

There are much better ways to provide a quantitative basis for risk-based decisions, but they will require a change of mindset for operational risk management teams. If Covid-19 has affected the company's risk position, it is likely that more risks are now outside the previously agreed risk appetite. In this case, existing risk mitigation measures should be reassessed.

\subsection{Internal audit}

"Desperate times needs desperate measures!". This phrase probably comes from a saying of the ancient Greek physician Hippocrates, which appears in his aphorisms: "For extreme diseases, extreme methods of healing, in terms of restriction, are the most appropriate." Or, translated in the context of the global pandemic caused by the new coronavirus, under adverse circumstances, actions that could have been rejected in other situations may become the best choice.

With the emergence of the global crisis generated by Covid-19, the internal public audit activity had to adapt and reconsider its approach of achieving the initially approved audit plans and missions. Therefore, there was a need to adjust and rethink the priorities of this internal control tool to support managers and to face the new challenges.

At international level, there has been a tendency for key players in this activity to attend internal emergency committee meetings and to be closer to management by providing advice and solutions to important operations carried out during the crisis (KPMG, 2020). According to KPMG's assessment, some internal audit structures are working to increase the concentration of internal audit activities for key areas of high-risk business, such as IT security and cyber security risks due to the considerable increase in remote work.

Current internal audit challenges include making audits more flexible due to changes in the environment and the economic and social context. This flexibility should take into account, from the outset planning which should recognize the limitations and restrictions faced by organizations and the concentration of audits in their key areas, continuing with the execution and fieldwork of auditors in the context of travel limitations and as well as the limitations of technical capabilities in accessing databases and the audit procedures for obtaining the required evidence and concluding with the reporting phase, where the focus should be on key risks rather than overloading a person in difficulty, as the audit team should recognize the limited potential of management to address some issues in the short term.

Currently, due to the fluidity of the current situation, the opinion of international experts on internal audit is that it should focus more on designing a continuous monitoring program around Covid-19 instead of performing a typical, long-term audit. A flexible audit style is required, in which topics should be chosen for very short periods of time and brief and timely reviews should be conducted 
only on the key activities of the organization. With this approach, the internal audit can follow the existing situation and provide up-to-date answers to senior management.

Internal audit is considered to bring more added value in supporting these processes from a consultative approach, rather than overlapping an audit on a period of crisis.

In Romania, the latest special report prepared by the Romanian Court of Accounts on the activity of internal public audit structures at the level of local public administration authorities radiographs the internal public audit as a deficient activity, both from an organizational perspective and from the perspective of its effectiveness and efficiency. According to this report, in 2018 at least $30 \%$ of the evaluated institutions did not have an internal public audit structure, while at $49 \%$ of them the audit was exercised in a system of cooperation by associations established for this purpose, based on a quite rigid calendar and having behind it a cumbersome decision-making system, which does not allow sufficiently rapid reactions to the changes generated by COVID-19 (Romanian Court of Accounts, 2020).

Considering the new conditions imposed by the state of emergency generated by Covid-19 in Romania, the public internal audit activity had to adapt, according to the latest study conducted by UCAAPI. Considering the new conditions imposed by the state of emergency generated by Covid19 in Romania, the public internal audit activity had to adapt, according to the latest study conducted by UCAAPI (Ministry of Public Finance, 2020). The study found that approximately $58 \%$ of the internal audit structures performed the audit missions in the first part of 2020 of the approved audit plan and over $74 \%$ of the internal audit missions were performed normally or with short site visits.

The problems did not take long to appear for the audit actions carried out in 2020 according to the plan (extended deadlines, limited availability of the audited persons), the survey respondents considering that an adjustment of the annual plan is necessary. During the state of emergency, activities were also carried out in support of public entities to manage the difficulties encountered, consisting mainly of assurance missions and informal advice to management (these aimed at identifying obstacles to the normal conduct of processes, establishing their causes, determining the consequences and presenting solutions to eliminate them). Some auditors were also involved in other activities specific to this exceptional situation.

These advisory tasks, regulated by the internal audit standards as well as by the texts of the normative acts in force, must be used especially in such emergency situations, or if not, even reinvented. These data reveal that, in Romania, the heads of internal audit structures have not yet made a sufficient adjustment of the activity and a rethinking of the priorities of the respective institutions, the audit capacities being still used for carrying out standard actions, apparently in antithesis to the international approach.

Even so, similar to the international approach, the study showed that during the state of emergency generated by Covid-19, internal audit must play a proactive role, with internal public auditors able to provide support to entity management through the experience and skills they have.

\subsection{Changes in the legislative framework}

Given the novelty of the situation generated by the emergence of the new virus, in response it was necessary to create a specific legislative framework in order to establish specific measures to combat the epidemic and to use public funds. Thus, the President of Romania issued two decrees for the establishment and, subsequently, the extension of the state of emergency. Both decrees, which aimed to prevent the spread of the epidemic through various restrictions, established a number of specific tasks for public institutions, which led to additional costs for them.

The mentioned decrees established first emergency measures, with direct and immediate applicability, but also first emergency measures with gradual applicability (implementation to be done by military ordinances, emergency ordinances, government decisions and ministerial orders). Consequently, during the state of emergency, several normative acts for the implementation of these 
decrees were elaborated and approved, being inventoried a number of 39 normative acts of primary level, 12 normative acts of secondary level and 75 normative acts of tertiary level.

These legal regulations covered several areas (public procurement, economic support, health, labor and social protection), their impact being felt in the allocation and use of public funds.

It should be noted that public procurement procedures for the establishment of emergency medical stocks have been conducted in a difficult international context, given the massive demand from all states affected by the pandemic.

In this regard, the European Commission, in its Guidance from the European Commission on using the public procurement framework in the emergency situation related to the COVID-19 crisis, recommended the application of the flexibility mechanisms available within the EU on public procurement in cases of extreme urgency, for quick acquisition of goods, services and works needed to deal with the crisis: recourse to the possibility of substantially reducing deadlines, the possibility of applying the negotiation procedure without publication, the application of alternative solutions and the establishment of market contacts (European Commission, 2020).

\subsection{Usage of financial resources in the emergency period}

The measures to combat the pandemic were supported mainly from public funds, which also played an important role in supporting the economy, which was severely affected during this period.

The first considered measure was the budgetary rectification approved by Emergency Ordinance no. $50 / 2020$ on the rectification of the state budget for year 2020. Thus, it was accepted the decrease of budget revenues by Ron 9,844.8 million, due to the reduction of activity in various economic sectors and the adoption of some budgetary fiscal measures, such as SME support program, extension of payment for some local taxes, non-calculation of interest and penalties of delay for the fiscal obligations due during the state of emergency and another 30 days from its termination, the technical unemployment indemnity for the period of suspension of the employment contract, the indemnity for authorized individuals or other professionals who do not have the quality of employers and interrupt their activity, allowance for parents staying at home with their children during a state of emergency, discount for companies paying corporate tax or income tax on microenterprises, deferral of customs duty on imports of medicines, protective equipment, other devices or medical equipment and sanitary materials that can be used in the prevention, limitation, treatment and control of COVID-19 (Romanian Government, 2020).

On the other hand, the level of expenditures was increased by RON 17,396.8 million for commitment appropriations and by RON 16,933.9 million for budget appropriations, in order to combat the pandemic and to mitigate the economic shock.

In this way, the budgets of the main authorizing officers with special tasks were supplemented, the main amounts allocated being as follows:,

Table 1. Structure of the amounts received by the main authorizing officers following the budgetary rectification approved by Emergency Ordinance no. 50/2020

\begin{tabular}{|l|c|l|}
\hline \multicolumn{1}{|c|}{ Authorizing officer } & $\begin{array}{c}\text { Amount received } \\
\text { (Ron million) }\end{array}$ & \multicolumn{1}{|c|}{ Main destination } \\
\hline $\begin{array}{l}\text { Ministry of Labor and } \\
\text { Social Protection }\end{array}$ & $8,103.9$ & $\begin{array}{l}\text { - special social protection measures during the state of emergency } \\
\text { - payment of social benefits established as a result of labor } \\
\text { disruptions during the state of emergency }\end{array}$ \\
\hline Ministry of Health & $3,796.4$ & $\begin{array}{l}\text { - health programs, emergency procurement of medical equipment } \\
\text { and supplies, risk incentives for medical staff }\end{array}$ \\
\hline Ministry of Public Finance & $3,215.0$ & - State aid scheme to support the activity of SMEs \\
\hline
\end{tabular}




\begin{tabular}{|l|c|l|}
\hline \multicolumn{1}{|c|}{ Authorizing officer } & $\begin{array}{c}\text { Amount received } \\
\text { (Ron million) }\end{array}$ & \multicolumn{1}{c|}{ Main destination } \\
\hline $\begin{array}{l}\text { Ministry of Public Works, } \\
\text { Development and } \\
\text { Administration }\end{array}$ & 1.000 .0 & - financing the National Local Development Program \\
\hline $\begin{array}{l}\text { Ministry of Internal } \\
\text { Affairs }\end{array}$ & 586.2 & $\begin{array}{l}\text { - ensuring expenditures to combat the spread of the pandemic } \\
\text { - emergency medical stocks }\end{array}$ \\
\hline
\end{tabular}

Source: authors' processing

Another measure concerned the Budget Reserve Fund available to the Government, from which funds were allocated for some main state budget officials as well as for all counties in the country, to which the total amount of Ron 15.6 million was directed for payment of quarantine expenses and those related to public social services staff in preventive isolation at work.

Allocations from this fund were made mainly for emergency medical stocks, medical unit preparation, the purchase of specific vehicles, protective masks for disadvantaged families and individuals, public information, quarantine and food allowance expenses, electronic devices for students from disadvantaged environments in order to carry out distance teaching activities, etc.

Donations and sponsorships amounting to Ron 214.7 million are added to these amounts destined to prevent and fight the pandemic, in cash or in kind, received by central and local public administration institutions.

Additional resources were mobilized at the level of local public administration, in order to achieve the additional tasks assigned in combating the pandemic. This was done by committing additional expenditure and budget corrections, where appropriate. In most cases, the budget corrections were made both by transfers of credits and by supplementing the initial provisions of the expenses with the assurance of the related financial resources (the Emergency Ordinance no. 29/2020 on some economic and fiscal measures allowed the transfers of credits in the first and second quarter of year).

Regarding the structure of resources used by the local public administration to combat the spread of the virus, the largest share was represented by the own resources of local budgets (Romanian Court of Accounts, 2020).

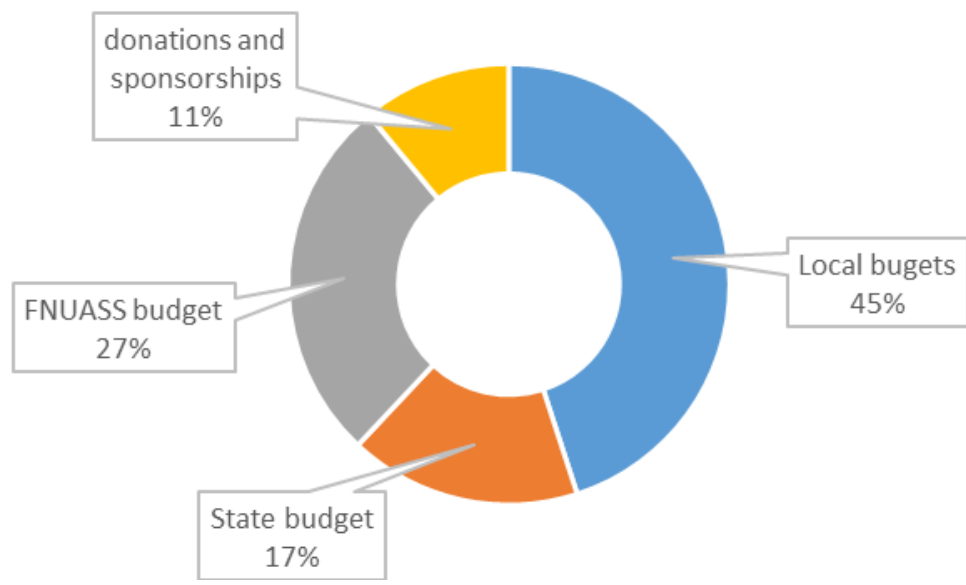

Figure 1. The structure of resources used by the local public administration to combat the pandemic during the state of emergency

Source: authors' processing 


\subsection{Irregularities in management of public funds}

Existing epidemiological context has led to the need to make emergency procurement for various products and services, as well as to support economic and public health programs.

However, the management of these public resources was not, in all cases, one that complied with the principles of legality, regularity and efficiency, according to the report made by Romanian Court of Accounts at Parliament's request. This resulted in a series of deficiencies in the way of committing and making these expenses, materialized in 825 cases of deviations, irregularities and / or errors, which generated:

- Ron 0.6 Million additional incomes;

- Ron 38.3 Million prejudices;

- financial accounting deviations of Ron 659 million.

The main types of irregularities found were as follows:

- at the level of the central public administration:

- non-compliance with the principles of "equal treatment" and "non-discrimination", where the tenders of some operators containing proposals to amend the contractual clauses set out in the award documentation being declared successful, clauses disadvantageous to the contracting authority;

- incorrect application of the direct procurement procedure, given that the estimated value of the procurement was higher than the threshold established by law;

- assignment of purchase agreement for a longer period than necessary to deal with the emergency situation;

- illegal payment to suppliers of some products / services (transport / delivery costs which were the responsibility of the supplier, expenses for quarantine of persons who did not comply with the isolation conditions or left the quarantine place, accommodation services settled at the level of maximum capacity and not at the actual level performed, purchase of equipment for which no documents have been submitted showing that they have been approved for sale by the competent institutions);

- commitment of budgetary credits without providing the contracted services within the term stipulated in the contract, non-calculation of penalties in case of non-compliance with the assumed delivery term;

- purchasing of goods at overvalued prices compared to the ones practiced on the profile market;

- making direct purchases without amounts provided in entity's budget;

- improper management of financial resources by paying substantial advances without immediately ensuring the purchase and distribution of acquired materials / equipment;

- payment of illegal personnel expenses (overtime granted to certain categories of personnel not provided for in the normative acts, undue or incorrectly calculated salary increases);

- payment of social protection benefits without complying with the legal framework (monthly allowance granted to other professionals whose activity has been interrupted, allowance paid to employees whose employers have reduced or interrupted the activity, allowance settled from the Guarantee Fund for the payment of salary claims related to parents who have been granted days off to supervise their children, in the event of the temporary closure of schools).

- at the level of the local public administration:

- direct procurement of goods by underestimating the elements necessary to determine the estimated value of public procurement and artificial division of procurement contracts;

- division of public procurement, resulting in the incorrect choice of the assignment procedure; 
- direct purchases of products, creating the appearance of making purchases initiated from the electronic catalog, without presenting proof of consulting the catalog or the market, the purchase being made directly from the supplier who delivered the products;

- illegal acceptance for payment and settlement of protective materials and equipment at prices higher than those initially offered, overvalued or for non-compliant equipment, not accompanied by documents of compliance and / or the opinion of the competent authority for their sale;

- granting specific staff rights to other categories of personnel than the ones entitled by law / in an amount higher than the legal one / without taking into account the actual time worked;

- payments of various social protection benefits without complying with the legal framework (erroneous determination of the number of working days for which the allowance should be granted, in case of temporary closure of schools, without taking into account the maximum level of $75 \%$ of gross salary used by the state social insurance budget;

- illegal payments of quarantine expenses (as a result of continued billing of accommodation services at rates set according to the number of quarantined persons, instead of rates set according to the rooms occupied by accommodation / for persons sanctioned for non-compliance with the self-isolation measure);

- payments for accommodation services not performed or for accommodation rates higher than those provided by law;

- services supplied by economic operators who were not authorized or who used non-compliant products.

\subsection{Analysis of the opinion of public entities regarding the implementation of the internal control system}

Regarding the capacity of the internal managerial control system to prevent risks and to detect errors that may occur in the activity of public entities, in the context of the urgency of decisionmaking and carrying out operations, the Romanian Court of Accounts report on the state of emergency alleges a lack of a framework guide for internal control specific to emergencies periods. Thus, some entities have identified vulnerabilities in terms of implementation and monitoring of operational procedures but also a superficial way of exercising their own preventive financial control, which created the premises for the occurrence of certain categories of financial-accounting deviations or generating of damages.

The same report also shows that, for the most part, public entities have proceeded to update and develop the internal management control system by taking specific measures (new activities to be undertaken, new associated risks have been identified, new operational procedures have been developed and implemented (Romanian Court of Accounts, 2020).

The existing situation, defined by ambiguities but also by a significant volume of financial resources made available to central and local authorities, has categorically increased the risks of compliance, fraud and corruption, putting even greater pressure on internal control systems already weak and void of operational procedures for such situations.

In order to identify the way in which public entities perceive the design and implementation of their internal managerial control system as well as its sufficiency and adequacy in detecting and preventing various irregularities, we prepared and distributed a questionnaire at the level of all public entities from Călărași County, regardless of their subordination, local or central. The questionnaire, based largely on Likert's scale, was addressed to all administrative units in the county (2 municipalities, 3 cities, 50 communes), as well as to entities subordinated to the central public administration. A number of 158 answers were received from employees from all levels of the institutions (employees with management or executive function, employees with accounting / control tasks / other tasks). 
Regarding the existing procedures, the results of the questionnaire were as follows:

- referring to the implementation (elaboration, approval and effective operationalization) of the operational procedures, the degree to which they cover all the activities carried out as well as their degree of detail, rigor and inflexibility, so as to describe in the smallest detail the work tasks, the answers were as follows:

Table 2. Questionnaire results regarding the implementation of operational procedures

\begin{tabular}{|l|c|c|c|c|c|}
\hline \multirow{2}{*}{ Measured criteria } & \multicolumn{5}{|c|}{ Score } \\
\cline { 2 - 6 } & $\begin{array}{c}\text { Total } \\
\text { disagreement }\end{array}$ & Disagreement & Neutral & Agreement & $\begin{array}{c}\text { Total } \\
\text { agreement }\end{array}$ \\
\hline $\begin{array}{l}\text { Implementation of } \\
\text { operational procedures }\end{array}$ & $3,2 \%$ & $2,5 \%$ & $6,4 \%$ & $23,6 \%$ & $64,3 \%$ \\
\hline $\begin{array}{l}\text { The degree of covering all } \\
\text { the activities }\end{array}$ & $2,5 \%$ & $5,7 \%$ & $7 \%$ & $38,9 \%$ & $45,9 \%$ \\
\hline Degree of rigor & $2,5 \%$ & $8,3 \%$ & $19,7 \%$ & $40,1 \%$ & $29,3 \%$ \\
\hline
\end{tabular}

Source: authors' processing

We note that, although the proportion of respondents saying „that there are operational procedures and that they cover the activities carried out, in terms of their rigor, the proportion is decreasing. In this case, an area that needs improvement was identified, for the procedures should be more imperative and inflexible as we descend to the lower levels of the entity, into the area of repetitive, routine actions, which must be more carefully controlled and whose effectiveness increases in terms of detailed descriptions of how they are performed (Russu, C. 1999).

- regarding the internal verification mechanisms (self-control, supervision, unannounced controls, other forms of internal control), the results are presented in the table below:

Table 3. Questionnaire results on internal verification mechanisms

\begin{tabular}{|l|c|c|c|c|c|}
\hline \multirow{2}{*}{ Measured criteria } & \multicolumn{5}{|c|}{ Score } \\
\cline { 2 - 6 } & $\begin{array}{c}\text { Total } \\
\text { disagreement }\end{array}$ & Disagreement & Neutral & Agreement & $\begin{array}{c}\text { Total } \\
\text { agreement }\end{array}$ \\
\hline $\begin{array}{l}\text { Existence of a supervising } \\
\text { procedure }\end{array}$ & $5,7 \%$ & $8,9 \%$ & $15,9 \%$ & $30,6 \%$ & $38,9 \%$ \\
\hline $\begin{array}{l}\text { Existence of self-control } \\
\text { mechanisms }\end{array}$ & $6,4 \%$ & $3,8 \%$ & $13,4 \%$ & $34,4 \%$ & $42 \%$ \\
\hline $\begin{array}{l}\text { Compliance with } \\
\text { supervision procedure }\end{array}$ & $4,5 \%$ & $5,7 \%$ & $13,4 \%$ & $27,4 \%$ & $49 \%$ \\
\hline $\begin{array}{l}\text { Existence of an internal } \\
\text { control procedure }\end{array}$ & $2,5 \%$ & $3,2 \%$ & $5,1 \%$ & $19,1 \%$ & $70,1 \%$ \\
\hline $\begin{array}{l}\text { Functionality of the } \\
\text { internal control procedure }\end{array}$ & $4,5 \%$ & $3,2 \%$ & $7,6 \%$ & $22,9 \%$ & $61,8 \%$ \\
\hline $\begin{array}{l}\text { Existence of unannounced } \\
\text { controls }\end{array}$ & $7,6 \%$ & $4,5 \%$ & $13,4 \%$ & $15,3 \%$ & $59,2 \%$ \\
\hline $\begin{array}{l}\text { Existence of internal } \\
\text { controls }\end{array}$ & $4,5 \%$ & $4,5 \%$ & $14,6 \%$ & $22,3 \%$ & $54,1 \%$ \\
\hline
\end{tabular}

Source: authors' processing

First of all, strengthening the supervision activities is an action that must be done, together with compliance to related procedures where they exist, as well as the transition from supervision formal character to an effective and efficient integration in the daily activity of the public entities. This is more obvious if we follow the frequency of these controls, as shown in the graph below, where the 
proportion of those who declare that the frequency of internal controls is greater than or equal to 3 months is $64 \%$ !

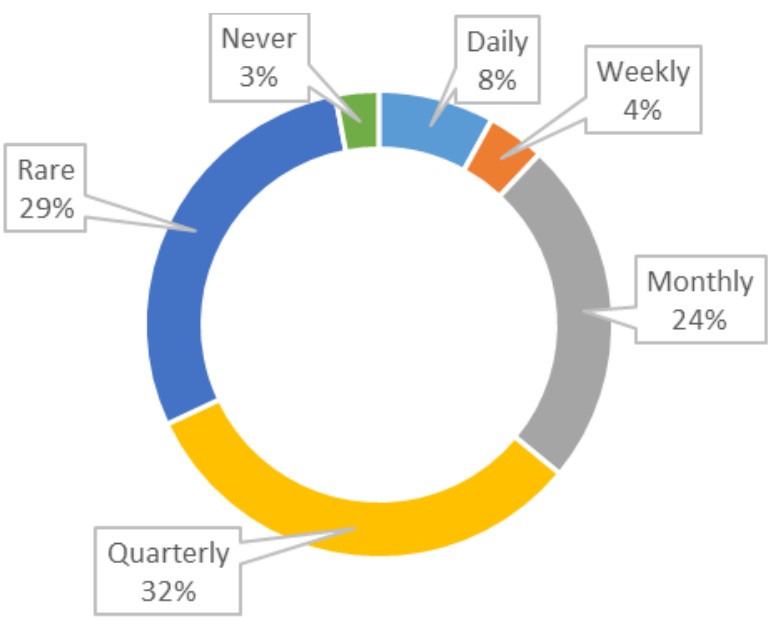

Figure 2. Internal controls frequency

Source: authors' processing

- referring to fraud reporting procedures, there is a significant percentage (30\%) of those who declare that they are not operational or does not exist, along with those who are indifferent to this aspect;

- irregularities in the activity carried out were found both by the internal control bodies (internal audit) but also by the external ones (various state control institutions) in 22-28\% of cases;

Table 4. Questionnaire results on fraud reporting procedures and irregularities detected (internal or external)

\begin{tabular}{|l|r|r|r|r|r|}
\hline \multicolumn{1}{|c|}{ Measured criteria } & \multicolumn{6}{|c|}{ Score } \\
\cline { 2 - 6 } & $\begin{array}{c}\text { Total } \\
\text { disagreement }\end{array}$ & Disagreement & Neutral & Agreement & $\begin{array}{c}\text { Total } \\
\text { agreement }\end{array}$ \\
\hline $\begin{array}{l}\text { Existence of fraud reporting } \\
\text { procedure }\end{array}$ & $8,3 \%$ & $5,1 \%$ & $16,6 \%$ & $19,7 \%$ & $50,3 \%$ \\
\hline $\begin{array}{l}\text { Irregularities found by } \\
\text { internal control bodies }\end{array}$ & $38,2 \%$ & $15,3 \%$ & $18,5 \%$ & $16,6 \%$ & $11,5 \%$ \\
\hline $\begin{array}{l}\text { Irregularities found by } \\
\text { external control authorities }\end{array}$ & $45,9 \%$ & $15,3 \%$ & $16,6 \%$ & $12,1 \%$ & $10,2 \%$ \\
\hline
\end{tabular}

Source: authors' processing

\section{CONCLUSIONS}

From the aspects showed above there are some conclusions that can be drawn. First of all, we cannot fully agree with the lack of an internal control framework guide specific to emergency situations, as invoked in the Romanian Court of Account's report, even though it showed that most entities did not develop and implement operational procedures for emergencies.

Internal managerial control is part of the management system of the entities, regardless of the period it crosses. It is or it is not implemented and functional. Moreover, the irregularities reported in the management of public funds during the state of emergency are more related to the way they are used (inefficient in some cases or even in violation of legal provisions, leading to damage), which is no different from managing these funds from a normal period. In addition, given the specificity of this period, the legislator has made the public procurement process more flexible, by resorting to a greater extent to direct procurement. Indeed, procedures are needed to manage such emergencies, 
from business continuity plans to procedures for setting up various reserves. Secondly, it is clear that control mechanisms can be improved, as they are the first step in detecting and preventing various harmful irregularities. Thus, greater emphasis should be placed on the extent to which the procedures cover all activities in public entities, but also on the degree of rigor and detail of them.

With regard to the supervision of the activities carried out, as defined by this standard of internal control in national legislation, there is a need for major improvements. As can be seen from the answers to the questionnaires submitted, presented above, in practice, the implementation of this standard is often deficient, being done rarely and only formally.

Greater emphasis should be placed on the implementation of various methods and techniques of supervision and control (e.g. the four-eyes principle, in which no operation performed by an employee is effectively operational and takes effect only when supervised / endorsed by another person, unannounced controls, verification of all operations that exceed a certain value threshold or those of an unusual nature related to the current activities carried out).

Last but not least, we can bring into discussion the non-imperative character of the legal provisions that regulates the development and deployment of the internal managerial control system in public institutions. The legal rules governing this management tool, important in terms of detecting errors, irregularities and reducing the opportunity element in the so-called fraud triangle, although welldefined and detailed enough, are devoid of any mandatory character. We recall here that, although the establishment, implementation and development of this instrument is a duty for management, there is no legal sanction or other way of constraint if this is not done.

Thus, it is necessary to make efforts to remove the formal nature of this management tool, to get out of the area where it is perceived only as an unnecessary load of workloads and use it more efficiently to eliminate the opportunity element of the fraud triangle.

No crisis, regardless of its nature, should be allowed to pass without drawing the necessary conclusions and without reflecting on the measures necessary to navigate in the future in similar situations and become more resilient. Moreover, organizations, both public and private, should focus their efforts on rethinking how their employees work with each other, with public or with customers, with the horizon that is currently opening up, indicating more than ever the need to improve internal work and communication technologies.

The COVID-19 crisis surely brings new challenges for the whole spectrum of organizations. In this sense, every component of organizations and every management tool we have (and internal managerial control is such a powerful one) should create added value to support the passage through these uncertain times.

\section{REFERENCES}

European Commission (2020). Official Journal of the European Union - Guidance from the European Commission on using the public procurement framework in the emergency situation related to the COVID-19 crisis. Retrieved October 1, 2020, from https:/eurlex.europa.eu/legal-content/en/TXT/PDF/?uri=CELEX:52020XC0401(05)\&from=en

Government of Romania (2020). 2020 Convergence Program, Retrieved October 1, 2020, from https://www.mfinante.gov.ro/static/10/Mfp/pdc/ProgramdeConvergenta2020_20052020.pdf

KPMG (2020). Impact of the COVID-19 crisis on Internal Audit Functions of financial institutions. Retrieved October 1, 2020, from https://home.kpmg/nl/nl/home/insights/2020/04/impact-ofthe-covid-19-crisis-on-internal-audit-functions-of-financial-institutions.html

Ministry of Public Finance - UCAAPI (2020). Public internal audit in Romania during COVID-19 pandemic, $\quad$ Retrieved October $1, \quad 2020, \quad$ from http://www.mfinante.ro/static/10/Mfp/audit/rezultatesondajsibunepractici_en.pdf 
PricewaterhouseCoopers (2020). Rethinking internal controls for pandemic recovery. Retrieved October 1, 2020, from https://www.pwc.be/en/FY20/documents/covid-19-whitepaperrethinking-internal-controls-for-pandemic-recovery.pdf

Romanian Court of Accounts (2020). Gestionarea resurselor publice în perioada stării de urgență, Retrieved October 1, 2020, from http://www.curteadeconturi.ro/Publicatii/Raport_stare_urgenta_11082020.pdf

Russu, C. (1999). Management strategic. Bucharest: Editura ALL Beck

The Risk Coalition (2020). Some COVID-19 lessons for Risk Management and Internal Audit, Retrieved October 1, 2020, from https://riskcoalition.org.uk/blog-posts/some-covid-19-lessonsfor-risk-management-and-internal-audit 